\title{
PENGARUH PROFITABILITAS, STRUKTUR AKTIVA, DAN PERTUMBUHAN PENJUALAN TERHADAP HARGA SAHAM DENGAN STRUKTUR MODAL SEBAGAI VARIABEL INTERVENING PADA PERUSAHAAN MANUFAKTUR DI BURSA EFEK INDONESIA
}

\author{
$\underline{\text { Nunky Rizka Mahapsari }}{ }^{1}$ \\ nunky.rizka@gmail.com
}

\author{
$\underline{\text { Abdullah Taman }^{2}}$ \\ Fakultas Ekonomi Universitas Negeri Yogyakarta
}

\begin{abstract}
ABSTRAK
Penelitian ini merupakan penelitian kausal komparatif.Metode pengumpulan data adalah studi pustaka dan studi dokumentasi.Populasi penelitian ini adalah perusahaan manufaktur yang listing di Bursa Efek Indonesia selama tahun 2009-2011.Metode analisis data menggunakan analisis regresi berganda dan diperluas dengan analisis jalur.

Hasil penelitian menunjukkan:(1) Tidak terdapat pengaruh positif profitabilitas terhadap struktur modal,(2) Tidak terdapat pengaruh negatif struktur aktiva terhadap struktur modal,(3) Terdapat pengaruh positif pertumbuhan penjualan terhadap struktur modal, (4) Tidak terdapat pengaruh negatif profitabilitas, struktur aktiva, dan pertumbuhan penjualan terhadap struktur modal, (5) Terdapat pengaruh positif profitabilitas terhadap harga saham, tidak terdapat pengaruh positif struktur aktiva terhadap harga saham, tidak terdapat pengaruh negatif pertumbuhan penjualan terhadap harga saham, terdapat pengaruh negatif struktur modal terhadap harga saham, (6) Terdapat pengaruh positif profitabilitas, struktur aktiva, dan pertumbuhan penjualan terhadap harga saham melalui struktur modal.
\end{abstract}

Kata Kunci: Profitabilitas, Struktur Aktiva, Pertumbuhan Penjualan, Struktur Modal, Harga Saham

\section{ABSTRACT}

This research is a causal comparison. The collecting data method is literature study and documentation study. This population study is manufacturing company listed on the Indonesia Stock Exchange during 2009-2011. Analizing data with multiple regression analityc method and expanded with path analityc.

The results showed: (1) There is no positive effect of profitability on capital structure, (2) There is no negative influence of the asset structure to capital structure, (3) There is a growing positive influence of sales to capital structure, (4) There is no negative effect of profitability, asset structure, and sales growth in the capital structure, (5) There is a positive profitability effect on stock prices, there is no positive effect on stock prices of asset structure, there is no negative effect of sales growth in the stock price, there is the negative effect of capital structure on stock prices, (6) There is the positive influence of profitability, asset structure, and sales growth in the share price through capital structure.

Keywords: Profitability, Asset Structure, Sales Growth, Capital Structure, Share Price

\footnotetext{
${ }^{1}$ Alumni Prodi Akuntansi Fakultas Ekonomi Universitas Negeri Yogyakarta

${ }^{2}$ Staf Pengajar Jurusan P. Akuntansi Fakultas Ekononi Universitas Negeri Yogyakarta
} 


\section{A. PENDAhuluan}

\section{Latar Belakang Masalah}

Kemajuan perekonomian suatu negara salah satunya dapat direfleksikan oleh aktivitas pasar modal yang ada di negara tersebut.Sebagai pasar yang sedang berkembang (emerging market), pergerakan harga saham di pasar modal Indonesia berfluktuasi relatif tinggi.Secara sederhana perubahan harga saham mencerminkan perubahan minat investor terhadap saham tersebut. Jika permintaan terhadap suatu saham tinggi maka harga saham tersebut akan cenderung naik, demikian sebaliknya. Kondisi tersebut dipengaruhi oleh beberapa faktor salah satunya adalah informasi dari luar perusahaan (eksternal), seperti daftar peringkat saham, tren yang sedang terjadi, dan lain-lain.

Analisis dan interprestasi berbagai rasio keuangan perusahaan dapat memberikan informasi yang baik mengenai kondisi perusahaan tersebut, baik dari segi keuangan maupun manajemen secara keseluruhan.Informasi tersebut sangat berguna bagi pengguna informasi seperti investor, kreditor, auditor, dan pihakpihak yang membutuhkan. Salah satu rasio yang biasa digunakan dalam mengukur tingkat kesehatan perusahaan adalah rasio profitabilitas yang dapat diukur dengan Return on Equity (ROE). Tingkat kesehatan perusahaan juga dapat diukur dari struktur aktiva di perusahaan tersebut. Struktur aktiva adalah kekayaan atau sumber-sumber ekonomi yang dimiliki oleh perusahaan yang diharapkan akan memberikan manfaat dimasa yang akan datang yang terdiri dari aktiva tetap, aktiva tidak berwujud, aktiva lancar, dan aktiva tidak lancar Titman dan Wessels (1988) dalam Ali Kesuma (2009).Selain struktur aktiva, pertumbuhan penjualan juga dapat ikut menggambarkan kesehatan sebuah perusahaan. Perusahaan yang sehat atau kinerjanya baik penjualannya akan cenderung selalu meningkat, namun peningkatannya tidak terlalu fluktuatif. Hal terpenting yang perlu diperhatikan perusahaan adalah mengenai struktur modal. Penyusunan struktur modal yang baik akan membuat kinerja perusahaan baik pula. Dalam penyusunan struktur modal, perusahaan perlu benar-benar mempertimbangkan berbagai hal, seperti stabilitas penjualan, struktur aktiva, laverage operasi, tingkat pertumbuhan, profitabilitas, pajak, pengendalian, sikap manajemen, sikap pemberi pinjaman dan agen pemeringkat, mondisi pasar, kondisi internal perusahaan, serta fleksibilitas keuangan (Brigham dan Houston,2006). 
Perubahan selera konsumen yang bervariasi dari ketiga industri tersebut akan menyebabkan perputaran laba menjadi lebih fluktuatif dan perputaran aktivanya pun juga akan lebih fluktiatif. Selain perputaran laba dan perputaran aktiva, perubahan selera konsumen juga akan berpengaruh pada perubahan penjualan yang fluktuatif juga. Kondisi yang tidak stabil ini bisa jadi berdampak pada harga saham.

Dari latar belakang tersebut, maka penelitian ini diberi judul "Pengaruh Profitabilitas, Struktur Aktiva, dan Pertumbuhan Penjualan Terhadap Harga Saham Dengan Struktur Modal Sebagai Varibel Intervening (Studi Empiris Pada Perusahaan Manufaktur Yang Listing Di Bursa Efek Indonesia)"

\section{B. KAJIAN PUSTAKA DAN PERUMUSAN HIPOTESIS}

1. Harga Saham

a. Pengertian Harga Saham

Tjiptono dan Hendi (2006:6) mendefinisikan saham sebagai tanda penyertaan atau pemilikan seseorang atau badan dalam suatu perusahaan atau perseroan terbatas.

b. Jenis-jenis Saham

Berdasarkan cara pengalihannya, saham dapat dibedakan menjadi dua jenis, yaitu:

1) Saham atas unjuk (bearer stock)

Pada sertifikat saham ini tidak dituliskan nama pemiliknya, agar mudah dipindahtangankan dari satu investor ke investor lain.

2) Saham atas nama (registered stock)

Pada sertifikat saham ini dituliskan nama pemiliknya. Cara peralihan dengan dokumen peralihan dan kemudian nama pemiliknya dicatat dengan buku perusahaan yang khusus memuat daftar nama pemegang saham.

Sedangkan berdasarkan kemampuan dalam hak tagih atau klaim saham dibedakan menjadi dua jenis, yaitu:

1) Saham biasa (common stock)

Saham biasa merupakan saham yang menempatkan pemiliknya pada posisi paling junior dalam pembagian dividen, dan hak atas kekayaan perusahaan apabila perusahaan tersebut dilikuidasi. 
2) Saham preferen (preferred stock)

Saham preferen merupakan saham yang memiliki kaakteristik gabungan antara obligasi dan saham biasa, karena bisa menghasilkan pendapatan tetap, tetapi juga bisa tidak mendatangkan hasil seperti yang diharapkan investor.

c. Pengertian Harga Saham

Menurut Jogiyanto (2008), "Harga saham adalah harga yang terjadi di pasar bursa pada saat tertentu yang ditentukan oleh pelaku pasar dan ditentukan oleh permintaan dan penawaran saham yang bersangkutan di pasar modal”. Sedangkan menurut Suad Husnan dan Enny Pudjiastuti (2004), harga saham merupakan nilai sekarang (present value) dari penghasilan-penghasilan yang akan diterima oleh pemodal dimasa yang akan datang. Harga saham yang digunakan dalam melakukan transaksi di pasar modal merupakan harga yang terbentuk dari mekanisme pasar yaitu permintaan dan penawaran pasar.Harga sebuah saham dapat berubah naik atau turun dalam hitungan waktu yang begitu cepat.Hal tersebut dimungkinkan karena banyaknya pesanan yang masuk.Oleh karena itu, investor ataupun pihak yang berkepentingan harus sering melihat atau mengecek posisi harga saham perusahaan melalui fasilitas yang ada.

2. Faktor-faktor yang Mempengaruhi Harga Saham

Faktor-faktor yang mempengaruhi fluktuasi harga saham dapat berasal dari internal maupun eksternal.Adapun faktor internalnya antara lain laba perusahaan, pertumbuhan aktiva tahunan, likuiditas, nilai kekayaan total, dan penjualan.Sedangkan faktor eksternalnya adalah kebijakan pemerintah dan dampaknya, pergerakan suku bunga, fluktuasi nilai tukar mata uang, rumor dan sentimen pasar, serta penggabungan usaha (business combination).

Harga saham dapat dibedakan menjadi 3 (tiga):

1) Harga Nominal

Harga yang tercantum dalam sertifikat saham yang ditetapkan oleh emiten untuk menilai setiap lembar saham yang dikeluarkan.

2) Harga Perdana

Harga ini merupakan harga pada waktu saham tersebut dicatat di bursa efek.

3) Harga pasar 
Harga pasar adalah harga jual dari investor yang satu dengan investor yang lain. Harga ini terjadi setelah saham tersebut dicatatkan di bursa.

3. Profitabilitas

a. Pengertian Profitabilitas

Menurut Sartono (2001) dalam Amanza (2012) profitabilitas adalah kemampuan perusahaan memperoleh laba dalam hubungannya dengan penjualan, total aktiva, maupun modal sendiri.Menurut Suad Husnan (1997) rasio profitabilitas dimaksudkan untuk mengukur efisiensi penggunaan aktiva perusahaan (atau mungkin sekelompok aktiva perusahaan).Profitabilitas suatu perusahaan diukur dari kemampuan perusahaan menggunakan aktivanya secara produktif, dengan membandingkan antara laba yang diperoleh dalam suatu periode dengan jumlah aktiva perusahaan tersebut.

b. Jenis-jenis Rasio Profitabilitas

Adapun jenis-jenis rasio profitabilitas adalah sebagai berikut :

1) Profit Margin (NPM)

2) Return On Assets (ROA)

3) Return On Equity (ROE)

4) Return On Investment (ROI)

5) Earning Per Share (EPS)

c. Pengaruh Profitabiltas Terhadap Harga Saham

Salah satu rasio Profitabilitas adalah Return on Equity (ROE). Return on Equity (ROE) digunakan untuk mengukur besarnya pengembalian terhadap investasi para pemegang saham. ROE membandingkan laba bersih setelah pajak (dikurangi dividen saham biasa) dengan ekuitas yang telah diinvestasikan pemegang saham di perusahaan.Angka tersebut menunjukkan seberapa baik manajemen memanfaatkan investasi para pemegang saham. Semakin besar ROE semakin besar pula harga saham karena besarnya ROE memberikan indikasi bahwa pengembalian yang akan diterima investor akan tinggi sehingga investor akan tertarik untuk membeli saham tersebut dan hal itu menyebabkan harga pasar saham cenderung naik.

4. Struktur Aktiva

a. Pengertian Struktur Aktiva 
Struktur aktiva menurut Titman dan Wessels (1988) dalam Ali Kesuma (2009) adalah kekayaan atau sumber-sumber ekonomi yang dimiliki oleh perusahaan yang diharapkan akan memberikan manfaat dimasa yang akan datang yang terdiri dari aktiva tetap, aktiva tidak berwujud, aktiva lancar, dan aktiva tidak lancar. Menurut Riyanto (1993:12) dalam Rina Walmiaty Mardi (2006): "Perbandingan atau perimbangan antara aktiva lancar dan aktiva tetap akan menentukan struktur kekayaan (struktur aktiva)".Struktur aktiva tercermin dalam sisi kiri suatu neraca, yang menunjukkan komposisi aktiva yang harus dibiayai.

b. Pengaruh Struktur Aktiva Terhadap Harga Saham

Berdasarkan hasil penelitian yang dilakukan oleh Ali Kesuma (2009) struktur aktiva memiliki pengaruh langsung yang berlawanan dengan harga saham. Semakin naik struktur aktiva berarti aktiva tetap yang dimiliki perusahaan akan meningkat yang berakibat modal kerja dan kemampuan dari perusahaan untuk memenuhi kewajiban perusahaan yang akan jatuh tempo menurun, sehingga perusahaan akan memerlukan modal dari saham, sehingga harga saham akan turun.

5. Pertumbuhan Penjualan

a. Pengertian Pertumbuhan Penjualan

Tingkat pertumbuhan penjualan menunjukkan tingkat perubahan penjualan dari tahun ke tahun. Semakin tinggi tingkat pertumbuhannya, suatu perusahaan akan lebih banyak mengandalkan pada modal eksternal. Menurut Brigham dan Houston (2006:42) sebuah perusahaan yang penjualannya relatif stabil akan aman dalam mengambil lebih banyak hutang dan menanggung beban tetap yang lebih tinggi daripada perusahaan yang penjualannya tidak stabil.

b. Pengaruh Pertumbuhan Penjualan Terhadap Harga Saham

Peningkatan penjualan dapat meningkatkan kemampuan perusahaan untuk memperoleh pendapatan dan laba perusahaan, dengan peningkatan penjualan tersebut, maka perusahaan dapat menutup biaya-biaya yang dikeluarkan untuk operasional perusahaan, dan memperbaiki struktur modal perusahaan karena perusahaan dapat membayar hutangnya dan dapat meningkatkan modal sendiri.Pertumbuhan penjualan memiliki pengaruh yang 
berlawanan arah dengan harga saham. Semakin tinggi tingkat pertumbuhan penjualan akan memerlukan modal kerja dan modal untuk investasi, sehingga harga saham akan turun.

6. Struktur Modal

a. Pengertian Struktur Modal

Menurut Joel G. Siegel dan Jae K. Shim (1999) dalam Irham Fahmi (2011) struktur modal adalah "komposisi saham biasa, saham preferen, dan berbagai kelas seperti itu, laba yang ditahan, dan utang jangka panjang yang dipertahankan oleh kesatuan usaha dalam mendanai aktiva".Struktur modal merupakan gambaran dari bentuk proporsi finansial perusahaan antara modal yang dimiliki yang bersumber dari utang jangka panjang (long-term liabilities) dan modal sendiri (shareholder's equity) yang menjadi sumber pembiayaan suatu perusahaan. Struktur modal suatu perusahaan terdiri dari long-term debt dan shareholder's equity, dimana shareholder's equity terdiri dari preferred stock dan common equity.

b. Pembagian Struktur Modal

Struktur Modal secara garis besar dapat dibedakan menjadi dua, yaitu:

1) Simple Capital Structure, yaitu jika perusahaan hanya menggunakan modal sendiri saja dalam struktur modalnya.

2) Complex Capital Structure, yaitu jika perusahaan tidak hanya menggunakan modal sendiri tetapi juga menggunakan modal pinjaman dalam struktur modalnya.

c. Faktor-faktor yang Menentukan Pemilihan Struktur Modal

Menurut Brigham dan Houston (2006:42) faktor-faktor yang perlu dipertimbangkan perusahaan ketika membuat keputusan struktur modal adalah stabilitas penjualan, struktur aktiva, laverage operasi, tingkat pertumbuhan, profitablitas, pajak, pengendalian, sikap manajemen, sikap pemberi pinjaman dan agen pemberi peringkat, kondisi pasar, kondisi internal perusahaan, fleksibilitas keuangan.

d. Pengaruh Sturktur Modal Terhadap Harga Saham 
Struktur modal bertujuan memadukan sumber dana permanen yang selanjutnya akan digunakan perusahaan dengan cara yang diharapkan mampu memaksimumkan nilai perusahaan. Keadaan struktur modal akan berakibat langsung pada posisi keuangan perusahaan sehingga mempengaruhi kinerja perusahaan. Struktur modal yang dapat memaksimumkan nilai perusahaan atau harga saham adalah struktur modal yang terbaik.

\section{Kerangka Berfikir}

Salah satu tolok ukur investor dalam menentukan investasinya adalah kinerja perusahaan.Kinerja perusahaan dapat dinilai dari harga saham perusahaan tersebut.Profitabilitas merupakan salah satu tolok ukur kesehatan perusahaan.Selain itu kesehatan perusahaan juga dapat dilihat dari keadaan aktiva yang ada di neraca. Hal lain yang dapat digunakan untuk mengukur kesehatan perusahaan adalah pertumbuhan penjualan. Semakin stabil penjualan yang terjadi di perusahaan maka kinerja perusahaan tersebut semakin baik.Setiap perusahaan harus pandai dalam menyusun struktur modalnya karena keadaan struktur modal akan berakibat langsung pada posisi keuangan perusahaan sehingga mempengaruhi kinerja perusahaan.

Adapun hipotesis dalam penelitian ini adalah sebagai berikut:

H1 : Terdapat pengaruh positif profitabilitas terhadap struktur modal.

H2 : Terdapat pengaruh negatif struktur aktiva terhadap struktur modal.

H3 : Terdapat pengaruh positif pertumbuhan penjualan terhadap struktur modal.

H4 : Terdapat pengaruh negatif profitabilitas, struktur aktiva, dan pertumbuhan penjualan terhadap struktur modal secara simultan.

H5 : Terdapat pengaruh profitabilitas, struktur aktiva, pertumbuhan penjualan, dan struktur modal terhadap harga saham secara parsial.

H6 : Terdapat pengaruh positif profitabilitas, struktur aktiva, dan pertumbuhan penjualan terhadap harga saham secara simultan melalui struktur modal.

\section{METODE PENELITIAN}


1. Desain Penelitian

Masalah dalam penelitian ini berupa hubungan sebab akibat, maka dari itu penelitian ini dikategorikan sebagai penelitian kausal komparatif yang dalam hal ini penelitian kausal komparatif termasuk dalam tipe penelitian ex post facto.Penelitian ex post facto mencoba menggali beberapa aspek dari objek penelitian dengan menggunakan instrumen yang telah diarsipkan sebelumnya tanpa melakukan manipulasi variabel terhadap subjek yang diteliti (Sugiyono, 2008: 6).

2. Populasi dan Sampel Penelitian

Penelitian ini menggunakan populasi perusahaan manufaktur, khususnya yang bergerak dalam industri barang konsumsi (makanan dan minuman), industri rokok, serta industri kosmetik dan keperluan rumah tangga yang tercatat di Bursa Efek Indonesia.Pengambilan sampel dalam penelitian ini menggunakan purposive sampling, dengan tujuan untuk mendapatkan sampel yang representative sesuai dengan kriteria yang ditentukan (Meythi, 2006:7).Terdapat 12 perusahaan yang memenuhi kriteria pemilihan sampel ini sehingga, total data adalah 36 data.

3. Jenis dan Sumber Data

Data yang digunakan dalam penelitian ini adalah data sekunder dari perusahaan manufaktur khususnya perusahaan yang bergerak di industri barang konsumsi (makanan dan minuman), industri rokok, serta industri kosmetik dan keperluan rumah tangga yang terdaftar pada Bursa Efek Indonesia (BEI), yaitu laporan tahunan ketiga sub sektor perusahaan yangtercatat pada periode 20092011.

4. Teknik Pengumpulan Data

Pengumpulan data diperoleh dengan mengakses situs di Bursa Efek Indonesia www.idx.co.id, ICMD (Indonesian Capital Market Directory), website perusahaan, pojok bursa Universitas Kristen Duta Wacana Yogyakarta dan sumber-sumber lain yang relevan.Metode pengumpulan data yang digunakan dalam penelitian ini adalah studi pustaka dan studi dokumentasi.

5. Teknik Analisis Data

a. Analisis Deskriptif

Analisis deskriptif digunakan dengan tujuan untuk memberikan gambaran atau deskripsi mengenai suatu data yang dilihat dari nilai rata-rata (mean), 
standar deviasi, maksimum, minimum, varian, sum, range, kurtosis dan skewness (kemencengan distribusi) (Imam Ghozali, 2005).

b. Pengujian Asumsi Klasik

1) Uji Normalitas

Uji normalitas bertujuan untuk menguji apakah dalam model regresi variabel terikat dan variabel bebas keduanya mempunyai terdistribusi secara normal atau tidak.Untuk mendeteksi normalitas data dalam penelitian ini digunakan uji data dengan kolmogorof-Smirnof karena hasilnya berupa angka, bukan gambar, maka lebih mudah untuk memutuskan residual berdistribusi normal atau tidak.

2) Uji Multikoliniearitas

Uji Multikoliniearitas betujuan untuk menguji apakah dalam regresi ditemukan hubungan antara variabel bebas atau tidak.Untuk mendeteksi ada atau tidaknya multikoliniearitas dalam model regresi dapat dilihat dari nilai toleransi dan nilai variance Inflation factor (VIF).

3) Uji Autokorelasi

Uji autokorelasi bertujuan untuk menguji apakah dalam suatu model regresi linier berganda terdapat korelasi antara kesalahan pengganggu pada periode $\mathrm{t}$ dengan kesalahan periode sebelumnya ( $\mathrm{t}-1$ ). Untuk menguji ada atau tidaknya problem autokorelasi dapat dilakukan uji Durbin Watson (DW test) yaitu dengan membandingkan nilai DW statistik dengan DW tabel.

4) Uji Heteroskedastisitas

Uji ini bertujuan untuk menguji apakah dalam model regresi terjadi ketidaksamaan variance dari residual satu pengamatan ke pengamatan yang lain. Salah satu cara untuk mengetahui ada tidaknya heteroskedastisitas dalam model regresi linier berganda adalah dengan melihat ada tidaknya pola tertentu pada grafik scatterplot antara variabel terikat yaitu ZPRED dengan residual error yaitu SRESID.

c. Pengujian Hipotesis

Penelitian ini menguji hipotesis dengan metode analisis regresi berganda. Penelitian ini bertujuan untuk menguji apakah profitabilitas, struktur aktiva, dan pertumbuhan penjualan berpengaruh terhadap harga saham dengan struktur 
modalsebagai variabel intervening. Persamaan structural dalam penelitian ini yaitu:

$$
\begin{aligned}
& Y_{1}=b_{1} Y_{1} X_{1}+b_{2} Y_{1} X_{2}+b_{3} Y_{1} X_{3}+E_{1} \\
& Y_{2}=b_{1} Y_{2} X_{1}+b_{2} Y_{2} Y_{1}+b_{3} Y_{2} X_{3}+E_{2}
\end{aligned}
$$

\section{HASIL PENELITIAN DAN PEMBAHASAN}

1. Deskripsi Data

Data sekunder dalam penelitian ini diperoleh dari situs resmi Bursa Efek Indonesia www.idx.co.id, ICMD (Indonesian Capital Market Directory), dan pojok bursa Universitas Kristen Duta Wacana Yogyakarta. Data yang terkumpul tersebut berupa laporan keuangan dari ketiga sub sektor perusahaan tersebut. Hasil pengolahan data berupa informasi yang digunakan untuk mengetahui pengaruh Profitabilitas, Struktur Aktiva, dan Pertumbuhan Penjualan terhadap Harga Saham dengan Struktur Modal sebagai variabel Intervening. Jumlah perusahaan yang digunakan dalam penelitian ini sebanyak 12 perusahaan.

2. Analisis Deskriptif

a. Profitabilitas

Hasil analisis data variabel profitabiltas menggunakan program SPSS diketahui bahwa nilai minimum profitabilitas sebesar 0,70 , dan nilai maksimum profitabilitas sebesar 323,59. Hasil tersebut menunjukkan bahwa nilai profitabilitas berkisar antara 0,70 sampai 323,59 dengan nilai rata-rata sebesar 36,9150 dan standar deviasi sebesar 58,28967.

b. Struktur Aktiva

Hasil analisis data variabel struktur akiva menggunakan program SPSS diketahui bahwa nilai minimum struktur aktiva sebesar 17,66 dan nilai maksimumnya sebesar 117,74. Hasil tersebut menunjukkan bahwa nilai struktur aktiva berkisar antara 17,66 sampai 117,74 dengan rata-rata sebesar 388,9303 dan standar deviasi sebesar 18,02533.

c. Pertumbuhan penjualan

Hasil analisis data variabel pertumbuhan penjualan menggunakan program SPSS diketahui bahwa nilai minimum pertumbuhan penjualan sebesar 0,43 dan nilai maksimum pertumbuhan penjualan sebesar 148,55. Hasil tersebut menunjukkan bahwa nilai pertumbuhan penjualan berkisar antara 0,43 
dampai dengan 148,55 dengan rata-rata sebesar 22,1872 dan standar deviasi sebesar 25,35687 .

d. Struktur modal

Hasil analisis data variabel struktur modal menggunakan program SPSS diketahui bahwa nilai minimum struktur modal sebesar 3,15 dan nilai maksimum struktur modal sebesar 143,91. Hasil tersebut menunjukkan bahwa nilai struktur modal berkisar antara 3,15 sampai 143,91 dengan rata-rata sebesar 32,3903 dan standar deviasi sebesar 41,86462.

e. Harga saham

Hasil analisis data variabel harga saham menggunakan program SPSS diketahui bahwa nilai minimum harga saham sebesar 205 dan nilai maksimum harga saham sebesar 359000.Hasil tersebut menunjukkan bahwa nilai harga saham berkisar antara 205 sampai 359000 dengan rata-rata sebesar 31174,5833 dan standar deviasi sebesar 77538,93230.

3. Pengujian Asumsi Klasik

a. Uji Normalitas

Uji normalitas bertujuan untuk menguji apakah dalam model regresi variabel terikat dan variabel bebas keduanya mempunyai terdistribusi secara normal atau tidak.

Tabel Hasil Uji Normalitas

\begin{tabular}{|l|l|l|l|}
\hline \multicolumn{1}{|c|}{ Variabel } & Kolmogorov-Smirnov & Sig. & Kesimpulan \\
\hline $\begin{array}{l}\text { Profitabilitas, Struktur Aktiva } \\
\text { Pertumbuhan Penjualan } \\
\text { Struktur Modal } \\
\text { Harga Saham }\end{array}$ & 0,633 & 0,818 & Normal \\
\hline
\end{tabular}

b. Uji Multikolinieritas

Uji Multikoliniearitas betujuan untuk menguji apakah dalam regresi ditemukan pengaruh antara variabel bebas atau tidak.

Tabel Hasil Uji Multikolinieritas

\begin{tabular}{|l|l|l|l|}
\hline Variabel & Tolerance & VIF & Kesimpulan \\
\hline Profitabilitas, & 0,986 & 1,014 & Tidak ada multikolinieritas \\
\hline Struktur Aktiva & 0,974 & 1,027 & Tidak ada multikolinieritas \\
\hline
\end{tabular}




\begin{tabular}{|l|l|l|l|}
\hline Variabel & Tolerance & VIF & Kesimpulan \\
\hline Pertumbuhan Penjualan & 0,865 & 1,156 & Tidak ada multikolinieritas \\
\hline Struktur Modal & 0,882 & 1,134 & Tidak ada multikolinieritas \\
\hline
\end{tabular}

c. Uji Autokorelasi

Uji autokorelasi bertujuan untuk menguji apakah dalam suatu model regresi linier berganda terdapat korelasi antara kesalahan pengganggu pada periode $t$ dengan kesalahan periode sebelumnya (t-1).

Tabel Hasil Uji Autokorelasi

\begin{tabular}{|l|l|}
\hline 'Nilai $\boldsymbol{D}$-W & Kesimpulan \\
\hline 2,104 & Tidak ada Autokorelasi \\
\hline
\end{tabular}

d. Uji Heteroskedastisitas Data

Uji ini bertujuan untuk menguji apakah dalam model regresi terjadi ketidaksamaan variance dari residual satu pengamatan ke pengamatan yang lain.

Gambar Hasil Uji Heteroskedastisitas

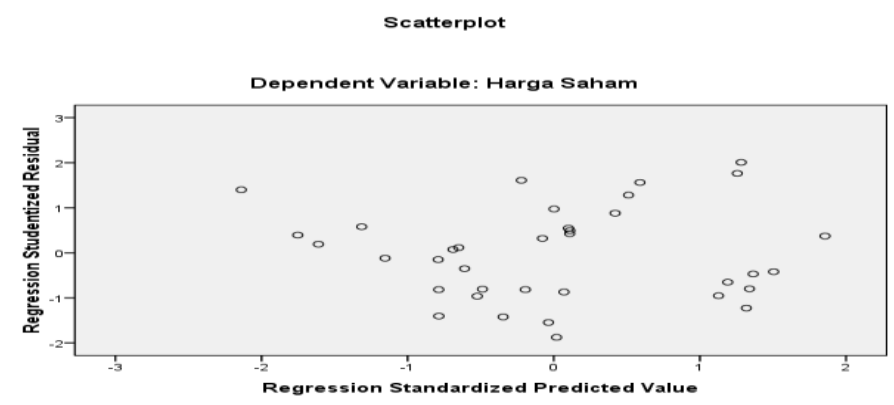

4. Uji Hipotesis

a. Pengujian Persamaan Pertama

Pengujian hipotesis menggunakan regresi berganda.

Tabel Hasil Analisis Regresi Profitabilitas, Struktur Aktiva, dan Pertumbuhan Penjualan terhadap Struktur Modal

\begin{tabular}{|c|c|c|c|c|c|}
\hline \multirow{2}{*}{ Model } & \multicolumn{2}{|c|}{$\begin{array}{c}\text { Unstandardized } \\
\text { Coefficients }\end{array}$} & \multirow{2}{*}{ 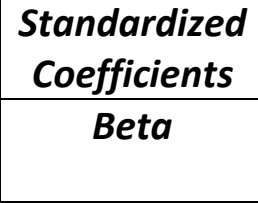 } & \multirow[t]{2}{*}{$t$} & \multirow[t]{2}{*}{ Sig } \\
\hline & B & $\begin{array}{l}\text { Std. } \\
\text { Error }\end{array}$ & & & \\
\hline (Constant) & $-0,991$ & 2,112 & & $-0,470$ & 0,642 \\
\hline Profitabilitas & $-0,078$ & 0,158 & $-0,080$ & $-0,492$ & 0,626 \\
\hline Struktur Aktiva & 0,715 & 0,525 & 0,224 & 1,363 & 0,183 \\
\hline
\end{tabular}




\begin{tabular}{|l|l|l|l|l|l|}
\hline $\begin{array}{l}\text { Pertumbuhan } \\
\text { Penjualan }\end{array}$ & 0,490 & 0,216 & 0,373 & 2,263 & 0,031 \\
\hline
\end{tabular}

1) Pengaruh Profitabilitas terhadap Struktur Modal

Hasil nilai signifikansi untuk profitabilitas sebesar 0,626/62,6\% > alpha $=$ $5 \%$, dan nilai t hitung sebesar $-0,492<$ nilai t tabel; $\mathrm{df}=(\mathrm{N}-2)=\mathrm{df}(36-2)$; $\operatorname{df}(34)=2,0322$ dengan alpha 5\%, berarti tidak terdapat pengaruh positif profitabilitas terhadap struktur modal. Besarnya pengaruh profitabilitas terhadap struktur modal dilihat dari unstandardized coefficient (Beta) yaitu sebesar $-0,078$ atau $-7,8 \%$.

2) Pengaruh Struktur Aktiva terhadap Struktur Modal

Hasil nilai signifikansi untuk struktur aktiva sebesar 0,183/18,3\% > alpha $=$ $5 \%$, dan $\mathrm{t}$ hitung sebesar $1,363<$ nilai $\mathrm{t}$ tabel $\mathrm{df}=(\mathrm{N}-2)=\mathrm{df}(36-2) ; \mathrm{df}(34)=$ 2,0322 dengan alpha 5\%, berarti tidak terdapat pengaruh negatif struktur aktiva terhadap struktur modal. Besarnya pengaruh struktur aktiva terhadap struktur modal dilihat dari unstandardized coefficient (Beta) yaitu sebesar 0,715 atau $71,5 \%$.

3) Pengaruh Pertumbuhan Penjualan terhadap Struktur Modal

Hasil nilai signifikansi untuk pertumbuhan penjualan sebesar 0,031/3,1\% < alpha $=5 \%$, dan nilai $\mathrm{t}$ hitung sebesar 2,263 > nilai t tabel $\mathrm{df}=(\mathrm{N}-2)=\mathrm{df}(36$ 2); $\operatorname{df}(34)=2,0322$ dengan alpha $5 \%$, berarti terdapat pengaruh positif pertumbuhan penjualan terhadap struktur modal. Besarnya pengaruh pertumbuhan penjualan terhadap struktur modal dilihat dari unstandardized coefficient (Beta) yaitu sebesar 0,490 atau $49 \%$.

4) Pengaruh profitabilitas, struktur aktiva, dan pertumbuhan penjualan terhadap struktur modal secara simultan.

Tabel Hasil Korelasi Berganda Profitabilitas, Struktur Aktiva, dan Pertumbuhan Penjualan terhadap Struktur Modal

\begin{tabular}{|l|c|l|l|l|}
\hline Model & $\boldsymbol{R}$ & $\boldsymbol{R}$ Square & $\begin{array}{c}\text { Adjusted } \boldsymbol{R} \\
\text { Square }\end{array}$ & $\begin{array}{c}\text { Std. Error of the } \\
\text { Estimate }\end{array}$ \\
\hline 1 & 0,403 & 0,163 & 0,084 & 1,21907 \\
\hline
\end{tabular}

\begin{tabular}{|l|l|l|l|c|c|}
\hline \multicolumn{1}{|c|}{ Model } & \multicolumn{1}{|c|}{$\begin{array}{c}\text { Sum of } \\
\text { Squares }\end{array}$} & $\boldsymbol{d} \boldsymbol{f}$ & Mean Square & $\boldsymbol{F}$ & Sig \\
\hline Regression & 9,232 & 3 & 3,007 & 2,071 & 0,124 \\
Residual & 47,556 & 32 & 1,486 & & \\
Total & 56,789 & 35 & & & \\
\hline
\end{tabular}


Hasil nilai signifikansi untuk ketiga variabel independen secara simultan adalah sebesar $0,124 / 12,4 \%>$ alpha $=5 \%$. F tabel $=$ F5\%; $\mathrm{df}(\mathrm{N}-\mathrm{m}-1)=(36-$ $3-1) ; \operatorname{df}(32)=2,90$ dan $F$ hitung sebesar 2,071 < F tabel 2,90, berarti tidak terdapat pengaruh negatif profitabilitas, struktur aktiva, dan pertumbuhan penjualan secara simultan terhadap struktur modal.Ketiga variabel independen tersebut dapat menjelaskan hubungan yang terjadi dengan harga saham atau disebut dengan koefisien determiniasi (D) ditunjukkan oleh $R$ Square sebesar 0,163 atau 16,3\%. Sedangkan sisanya sebesar 83,7\% dijelaskan oleh variabel independen lainnya. Berdasarkan uji regresi yang sudah dilakukan, maka model persamaan pertama untuk dua jalur adalah sebagai berikut: $\mathrm{Y}_{1}=-0,078 \mathrm{X}_{1}+0,715 \mathrm{X}_{2}+0,490 \mathrm{X}_{3}+83,7 \%$

b. Pengujian Persamaan Kedua

Pengujian hipotesis menggunakan regresi berganda.

Tabel Hasil Analisis Regresi Profitabilitas, Struktur Aktiva, Pertumbuhan Penjualan, dan Struktur Modal terhadap Harga Saham

\begin{tabular}{|l|l|l|l|l|c|}
\hline \multirow{2}{*}{ Model } & \multicolumn{2}{|c|}{$\begin{array}{c}\text { Unstandardized } \\
\text { Coefficients }\end{array}$} & $\begin{array}{c}\text { Standardized } \\
\text { Coefficient }\end{array}$ & \multirow{2}{*}{ t } & \multirow{2}{*}{ Sig } \\
\cline { 2 - 4 } & B & Std.Error & Beta & & \\
\hline (Constant) & 7,799 & 2,037 & & 3,829 & 0,001 \\
\hline Profitabilitas & 1,335 & 0,153 & 0,798 & 8,748 & 0,000 \\
\hline Struktur Aktiva & $-0,704$ & 0,519 & $-0,129$ & $-1,356$ & 0,185 \\
\hline $\begin{array}{l}\text { Pertumbuhan } \\
\text { Penjualan }\end{array}$ & 0,097 & 0,224 & 0,043 & 0,433 & 0,668 \\
\hline Struktur Modal & $-0,421$ & 0,170 & $-0,246$ & $-2,479$ & 0,019 \\
\hline
\end{tabular}

1) Pengaruh profitabilitas, struktur aktiva, pertumbuhan penjualan, dan struktur modal terhadap harga saham secara parsial.

Hasil nilai signifikansi untuk profitabilitas sebesar $0,000 / 0 \%<$ alpha $=5 \%$, dan nilai $\mathrm{t}$ hitung sebesar $8,748>$ nilai $\mathrm{t}$ tabel; $\mathrm{df}=(\mathrm{N}-2)=\mathrm{df}(36-2)$; $\mathrm{df}(34)=$ 2.0322 dengan alpha 5\%,berarti terdapat pengaruh positif profitabilitas terhadap harga saham. Besarnya pengaruh profitabilitas terhadap harga saham dilihat dari unstandardized coefficient (Beta) yaitu sebesar 1,335 atau $113,5 \%$.Hasil nilai signifikansi untuk struktur aktiva sebesar 0,185/ 18,5\% > alpha $=5 \%$, dan $\mathrm{t}$ hitung sebesar $-1,356<$ nilai $\mathrm{t}$ tabel; $\mathrm{df}=(\mathrm{N}-2)=\mathrm{df}(36-2)$; $\operatorname{df}(34)=2,0322$ dengan alpha $5 \%$, berarti tidak terdapat pengaruh positif struktur aktiva terhadap harga saham. Besarnya pengaruh struktur aktiva 
terhadap harga saham dilihat dari unstandardized coefficient (Beta) yaitu sebesar -0,704atau -70,4\%.Hasil nilai signifikansi untuk pertumbuhan penjualan sebesar $0,668 / 66,8 \%>$ alpha $=5 \%$, dan nilai $\mathrm{t}$ hitung sebesar $0,433<$ nilai $\mathrm{t}$ tabel; $\mathrm{df}=(\mathrm{N}-2)=\mathrm{df}(36-2) ; \mathrm{df}(34)=2,0322$ dengan alpha $5 \%$, berarti tidak terdapat pengaruh negatif pertumbuhan penjualan terhadap harga saham. Besarnya pengaruh pertumbuhan penjualan terhadap harga saham dilihat dari unstandardized coefficient (Beta) yaitu sebesar 0,097 atau 9,7\%. Hasil nilai signifikansi untuk struktur modal sebesar 0,019/1,9\% < alpha $=5 \%$, dan nilai $\mathrm{t}$ hitung sebesar $-2,479>$ nilai $\mathrm{t}$ tabel; $\mathrm{df}=(\mathrm{N}-$ $2)=\mathrm{df}(36-2) ; \operatorname{df}(34)=-2,0322$, atau $\mathrm{t}$ hitung berada di antara $-2,0322$ dan $+2,0322$ dengan alpha 5\%, maka $\mathrm{H}_{0}$ ditolak berarti terdapat pengaruh negatif struktur modal terhadap harga saham. Besarnya pengaruh struktur modal terhadap harga saham dilihat dari unstandardized coefficient (Beta) yaitu sebesar $-0,421$ atau $-42,1 \%$.

2) Pengaruh profitabilitas, struktur aktiva, pertumbuhan penjualan, dan struktur modal terhadap harga saham secara simultan.

Tabel Korelasi Berganda Profitabilitas, Struktur Aktiva, dan Struktur Modal terhadap Harga Saham

\begin{tabular}{|l|c|l|l|l|}
\hline Model & $\boldsymbol{R}$ & $\boldsymbol{R}$ Square & $\begin{array}{c}\text { Adjusted } \boldsymbol{R} \\
\text { Square }\end{array}$ & $\begin{array}{c}\text { Std. Error of the } \\
\text { Estimate }\end{array}$ \\
\hline 1 & 0,863 & 0,745 & 0,712 & 1,17193 \\
\hline
\end{tabular}

\begin{tabular}{|l|l|l|l|c|c|}
\hline \multicolumn{1}{|c|}{ Model } & $\begin{array}{l}\text { Sum of } \\
\text { Squares }\end{array}$ & \multicolumn{1}{c|}{$\boldsymbol{d f}$} & Mean Square & $\boldsymbol{F}$ & Sig. \\
\hline $\begin{array}{l}\text { Regression } \\
\text { Residual }\end{array}$ & 124,074 & 4 & 31,019 & 22,585 & 0,000 \\
Total & 166,650 & 31 & 1,373 & & \\
\hline
\end{tabular}

Hasil nilai signifikansi untuk keempat variabel independen secara simultan adalah sebesar $0,000 / 0 \%<$ alpha $=5 \%$. F tabel $=\mathrm{F} 5 \%$; $\mathrm{df}(\mathrm{N}-\mathrm{m}-1)=(36-3-$ 1); $\operatorname{df}(32)=2,90$ dan $F$ hitung sebesar 22,585> F tabel 2,90, berarti terdapat pengaruh positif profitabilitas, struktur aktiva,pertumbuhan penjualan, dan struktur modal secara simultan terhadap harga saham. Keempat variabel independen tersebut dapat menjelaskan hubungan yang terjadi dengan harga saham atau disebut dengan koefisien determiniasi (D) ditunjukkan oleh $R$ Square sebesar 0,745 atau $74,5 \%$. sedangkan sisanya sebesar $25,5 \%$ 
dijelaskan oleh variabel independen lainnya. Berdasarkan uji regresi yang sudah dilakukan, maka model persamaan pertama untuk dua jalur adalah sebagai berikut: $\mathrm{Y}_{2}=1,335 \mathrm{X}_{1}-0,421 \mathrm{Y}_{1}+0,097 \mathrm{X}_{3}+25,5 \%$

5. Pembahasan

a. Terdapat Pengaruh Profitabilitas Terhadap Struktur Modal

Hasil uji koefisien regresi diperoleh nilai t hitung sebesar -0,492 dengan nilai signifikansi $\mathrm{t}>\alpha(0,626>0,05)$ sehingga dapat disimpulkan bahwa tidak terdapat pengaruh positifprofitabilitas terhadap struktur modal pada perusahaan manufaktur yang listing di Bursa Efek Indonesia.

b. Tardapat Pengaruh Struktur Aktiva Terhadap Struktur Modal

Hasil uji koefisien regresi diperoleh nilai t hitung sebesar 1,363 dengan nilai signifikansi $\mathrm{t}>\alpha(0,183>0,05)$ sehingga dapat disimpulkan bahwa tidak terdapat pengaruh negatif struktur aktiva terhadap struktur modal pada perusahaan manufaktur yang listing di Bursa Efek Indonesia.

c. Terdapat Pengaruh Pertumbuhan Penjualan Terhadap Struktur Modal

Hasil uji koefisien regresi diperoleh nilai t hitung sebesar 2,263 dengan nilai signifikansi $\mathrm{t}<\alpha(0,031<0,05)$ sehingga dapat disimpulkan bahwa terdapat pengaruh positif pertumbuhan penjualan terhadap struktur modal pada perusahaan manufaktur yang listing di Bursa Efek Indonesia.

d. Terdapat Pengaruh Profitabilitas, Struktur Aktiva, dan Pertumbuhan Penjualan terhadap Struktur Modal Secara Simultan

Hasil uji koefisien regresi berganda diperoleh nila F hitung sebesar 2,071 yang nilainya lebih kecil dari F tabel sebesar 2,90. Dengan demikian dapat disimpulkan bahwa tidak terdapat pengaruh negatif profitabilitas, struktur aktiva, dan pertumbuhan penjualan secara simultan terhadap struktur modal pada perusahaan manufaktur yang listingdi Bursa Efek Indonesia.

e. Terdapat Pengaruh Profitabilitas, Struktur Aktiva, Pertumbuhan Penjualan, dan Struktur Modal Terhadap Harga Saham secara Parsial

Hasil uji koefisien regresi diperoleh nilai t hitung untuk profitabilitas sebesar 8,748 dengan nilai signifikansi $\mathrm{t}<\alpha(0,000<0,05)$ sehingga dapat disimpulkan bahwa terdapat pengaruh positif profitabilitas terhadap harga saham pada perusahaan manufaktur yang listing di Bursa Efek Indonesia. Hasil uji koefisien regresi diperoleh nilai t hitung untuk struktur aktiva sebesar - 
1,356 dengan nilai signifikansi $\mathrm{t}>\alpha(0,185>0,05)$ sehingga dapat disimpulkan bahwa tidak terdapat pengaruh positif struktur aktiva terhadap harga saham pada perusahaan manufaktur yang listing di Bursa Efek Indonesia. Hasil uji koefisien regresi diperoleh nilai $t$ hitung untuk pertumbuhan penjualan sebesar 0,433 dengan nilai signifikansi $\mathrm{t}>\alpha(0,668>$ 0,05) sehingga dapat disimpulkan bahwa tidak terdapat pengaruh negatif pertumbuhan penjualan terhadap harga saham pada perusahaan manufaktur yang listing di Bursa Efek Indonesia. Hasil uji koefisien regresi diperoleh nilai t hitung untuk struktur modal sebesar -2,479 dengan nilai signifikansi $\mathrm{t}<\alpha$ $(0,019<0,05)$ sehingga dapat disimpulkan bahwa terdapat pengaruh negatif struktur modal terhadap harga saham pada perusahaan manufaktur yang listing di Bursa Efek Indonesia.

f. Terdapat pengaruh profitabilitas, struktur aktiva, dan pertumbuhan penjualan terhadap harga harga saham secara simultan melalui struktur modal.

Pengaruh tidak langsung profitabilitas, struktur aktiva, dan pertumbuhan penjualan terhadap harga saham melalui struktur modal dapat dilihat dari hasil uji hipotesis didapatkan koefisien determinasi yang ditunjukkan oleh $R$ Square sebesar 0,745 atau 74,5\% dan F hitung sebesar 22,585. Hasil tersebut menunjukkan bahwa terdapat pengaruh positifvariabel profitabilitas, struktur aktiva, dan pertumbuhan penjualan secara simultan terhadap harga saham setelah melalui struktur modal sebagai variabel intervening.

\section{E. PENUTUP}

1. Simpulan

a. Tidak terdapat pengaruh positif profitabilitas terhadap struktur modal.

b. Tidak terdapat pengaruh negatif struktur aktiva terhadap struktur modal.

c. Terdapat pengaruh positif pertumbuhan penjualan terhadap struktur modal.

d. Tidak terdapat pengaruh negatif profitabilitas, struktur aktiva, dan pertumbuhan penjualan terhadap struktur modal.

e. Terdapat pengaruh positif profitabilitas terhadap harga saham.Tidak terdapat pengaruh positif struktur aktiva terhadap harga saham. Tidak terdapat 
pengaruh negatif pertumbuhan penjualan terhadap harga saham. Terdapat pengaruh negatif struktur modal terhadap harga saham.

f. Terdapat pengaruh positif profitabilitas, struktur aktiva, dan pertumbuhan penjualan terhadap harga saham melalui struktur modal.

2) Saran

a. Bagi Manajemen

Dalam menentukan harga saham hendaknya manajer perusahaan memperhatikan faktor-faktor lain yang sering digunakan oleh investor dalam pembuatan keputusan berinvestasi, sehingga harga saham tersebut dapat diterima oleh investor, bukan hanya sebatas keputusan yang diambil oleh manajemen perusahaan.

b. Bagi investor

Bagi investor yang akan menanamkan sahamnya di perusahaan-perusahaan manufaktur yang listing di Bursa Efek Indonesia sebaiknya lebih memperhatikan kinerja keuangan perusahaan secara keseluruhan, terutama pada kebijakan manajemen dalam penetapan harga saham perusahaan, bukan hanya dilihat dari laporan laba rugi yang tercantum pada laporan keuangan perusahaan.

c. Bagi peneliti selanjutnya

Untuk penelitian selanjutnya sebaiknya menambah jumlah sampel, variabel penelitian, dan periode penelitian agar menghasilkan informasi yang lebih mendukung. Selain itu penambahan variabel yang diteliti juga diperlukan, seperti faktor lain di luar perusahaan yang kemungkinan berpengaruh terhadap harga saham seperti tingkat inflasi, nilai perusahaan, dan tingkat suku bunga perlu juga ditambahkan dalam penelitian. Penelitian selanjutnya perlu mencoba menggunakan metode lain diluar regresi berganda, misalnya Structural Equation Model (SEM).

\section{F. DAFTAR PUSTAKA}

Ali Kesuma. (2009). Analisis Faktor Yang Mempengaruhi Struktur Modal Serta Pengaruhnya Terhadap Harga Saham Perusahaan Real Estate Yang Go 
Public Di Bursa Efek Indonesia. Jurnal Manajemen dan Kewirausahaan vol.11 No.1, Maret 2009: 38 - 45.

Arya Hagaganta Amanza. (2012). Analisis Faktor-Faktor yang Mempengaruhi Praktik Peataan Laba (Income Smoothing).Skripsi Fakultas Ekonomika dan Bisnis Universitas Diponegoro Semarang.

Danang Sunyoto.(2011). Riset Bisnis dengan Analisis Jalur SPSS.Yogyakarta: Gava Media.

Edi Subiyantoro dan Fransisca Andreani.(2003). Analisis Faktor-Faktor Yang Mempengaruhi Harga Saham (Kasus Perusahaan Jasa Perhotelan Yang Terdaftar Di Pasar Modal Indonesia). Jurnal Manajemen dan Kewirausahaan vol.5 No.2, September 2003:171-180.

Eugene F. Brigham dan Joel F. Houston.(2006). Dasar Dasar Manajemen Keuangan. Jakarta: Salemba Empat.

Hongren, Charles T, Gary L. Sundem, John. A. Elliot. (1998). Pengantar Akuntansi Keuangan.6".ed. Jakarta: Salemba Empat.

Ikatan Akuntan Indonesia.(2007). Standar Akuntansi Keuangan.Jakarta : Salemba Empat.

Imam Ghozali. (2008). Aplikasi Analisis Multivariate Dengan Program IBM SPSS19. Semarang: Badan Penerbit Universitas Diponegoro.

Indah, Nurmalasari. Analisis Pegaruh Rasio Profitabilitas Terhadap Harga Saham Emiten LQ45 Yang Terdaftar Di Ursa Efek Indonesia Tahun 2005-2008. www.googlescholar.com.Diakses 8 oktober 2012.

Indriyo Gitosudarmo \& Basri.(2002). Manajemen Keuangan.Yogyakarta: BPFE. Irham Fahmi. (2011). Analisis Kinerja Keuangan. Bandung: Alfabeta.

Joel G. Siegel dan Jae K. Shim.(1999). Kamus Istilah Akuntansi, Terjemahan.Jakarta :

Elex Media Komputindo. Hlm. 69.

Jogiyanto, Hartono. (2008). Teori Portofolio dan Analisis Investasi.Edisi 5.

Yogyakarta: BPFE.

Meythi.(2006). Pengaruh Arus Kas Operasi Terhadap Harga Saham Dengan

Persistensi Laba Sebagai Variabel Intervening.Simposium Nasional Akuntansi Padang Vol 1, 23-26 Agustus 2006.

Meyulinda Aviana Elim dan Yusfarita. (2010). Pengaruh Struktur Aktiva, Tingkat Pertumbuhan Penjualan, Dan Rwturn On Assets Terhadap Struktur Modal 
Pada Perusahaan Manufaktur Di Bursa Efek Jakarta. Efektif jurnal bisnis dan ekonomi Vol 1, No 1. Fakultas Ekonomi Universitas Janabadra.

Muhammad Umar Mai. (2006). Analisis Variabel-Variabel Yang Mempengaruhi Struktur Modal Pada Perusahaan-Perusahaan LQ-45 Di Bursa Efek Jakarta. Ekonomika Hal. 228- 245. Politeknik Negeri Bandung.

Nina Febriyani dan Ceacilia Srimindarti. (2010). Faktor-Faktor Yang Mempengaruhi Struktur Modal Pada Perusahaan-Oerusahaan LQ45 Di Bursa Efek Indonesia Periode 2006-2008. Dinamika Keuangan dan Perbankan Vol 2 No 2

Universitas Stikubank Semarang.

Nur Indriantoro dan Bambang Supomo.(1999). Metodologi Penelitian Bisnis Untuk Akuntansi dan Manajemen.Edisi pertama. Yogyakarta: BPFE.

R. Agus. Sartono.(1990). ManajemenKeuangan, edisi kedua. Yogyakarta: BPFE.

Raden Mas Gian Ismoyo Kusumo.Analisis Pengaruh Rasio Keuangan Terhadap Return Saham Pada Perusahaan Non Bank. Diakses 1 November 2012 pukul 21.32 WIB

Ratih Kartika Dewi. (2011). Analisa Faktor-Faktor Yang Mempengaruhi Praktik Perataan Laba (Income Smoothing) Pada Perusahaan Manufaktur Dan Keuangan Yang Terdaftar Di BEI ( 2006 -2009 ).Skripsi Fakultas Ekonomi Universitas Diponegoro Semarang.

Rina Walmiati Mardy. (2008). Pengaruh Struktur Aktiva, Profitabilitas, Dan Kebijakan Dividen Terhadap Struktur Pendanaan.Tesis Sekolah Pascasarjana Universitas Sumatera Utara Medan.

Slamet Sugiri \& Sumiyana.(1996). Akuntansi Keuangan Menengah.Yogyakarta: AMP YKPN.

Stevanie Theodora Simatupang. (2010). Pengaruh Rasio Keuangan Dan Ukuran Perusahaan Terhadap Harga Saham Industri Barang Konsumen Yang Terdaftar Di Bursa Efek Indonesia.Skripsi Universitas Sumatera Utara. Suad Husnan (1997). Manajemen Keuangan. Teori dan Penerapan. Yokyakarta: BPFE. (1993). Pembelanjaan Perusahaan, edisi keempat. Yogyakarta: Liberty. 
Suad, Husnan dan Enny Pudjiastuti.(2006). Dasar Dasar Manajemen Keuangan.edisi kelima. Yogyakarta: UPP STIM YKPN.

Sugiyono.(2008). Metode Penelitian Bisnis.Bandung: CV Alfabeta.

Tita Deitiana. (2011). Pengaruh Rasio Keuangan, Pertumbuhan Penjualan dan Dividen Terhadap Harga Saham.Jurnal Bisnis dan Akuntansi, Vol 13, No 1.STIE Trisakti.

Titman and Wessels. 1998. Determinant of Capital Structure. The Journal of Finance.www.findarticles.com.

Tjiptono Darmaji \& Hendi M. Fakhrudin.(2011). Pasar Modal di Indonesia.3”.ed. Jakarta: Salemba Empat. (2006). Pasar modal di Indonesia pendekatan Tanya jawab. Jakarta: Salemba Empat.

Tubagus Ismail,dkk (2011). Pengaruh Eco-Control Terhadap Kinerja Ekonomi Dengan Kinerja Lingkungan Sebagai Variabel Intervening. Simposium Nasional Akuntansi XIV Aceh 2011.

Weston, J Fred and Thomas E. Copeland.(1986). Manajemen Keuangan, Terjemahan, edisi kedelapan, jilid 2. Jakarta: Binarupa Aksara. Hlm. 68. 